\title{
Histologic Features of Uterine Septum
}

\author{
Mohamed Ibrahim Mohamed Amer ${ }^{1}$, Laila Nabegh Mohammed Nageeb ${ }^{2}$, Walid ElBasuony \\ Mohammed ${ }^{1}$, Ahmed Hefny Abdo Abdo Hefny ${ }^{1}$
}

1- Obstetrics and Gynecology Department, Faculty of Medicine, Ain Shams University

2 -Pathology Department, Faculty of Medicine, Ain Shams University

Corresponding Author: Ahmed Hefny Abdo Abdo Hefny, E-mail: Hfni_hmd@yahoo.com, Tel: 01000074984

\begin{abstract}
Aim of the Work: this study aimed to detect the assessment of the histological features of the uterine septum as regard the proportion of muscle fibers in relation to fibrous tissue to decide the best management whether incision or excision.Patients and Methods: this study was carried out on 16 women with uterine septum in childbearing period complaining of either infertility or recurrent miscarriage fulfilling the inclusion criteria, attending to Ain Shams University Maternity Hospital between May 2017 and April 2018. The septum was incised or excised by scissors or by resectoscope and then specimen was taken from the middle of the septum sample (A) and another specimen from the uterine wall sample (B). The retraction of the septal tissue on both sides was observed. This study included 16 specimens of uterine septum (A) and 16 specimens from uterine wall (B). Histopathological examination was done. Results: there was a statistical significant difference between the uterine septum and uterine wall regarding amount of fibrous tissue, number of cells in the connective tissue, amount of muscle tissue, amount of capillaries and number of vessels with muscle wall $(\mathrm{P}<0.05)$. Poor retraction of the septal tissue was found in the muscular septum in contrast to good retraction that found in the fibrous septum. Conclusion: poor retraction of the septal tissue was found in the muscular septum in contrast to good retraction that found in fibrous septum.
\end{abstract}

Keywords: histologic features, uterine septum, septal tissue retraction

\section{INTRODUCTION}

Uterine anomalies were described in the 1800 s by Cruveilhier and Von Rokitansky (1). It is unclear what the exact rate of Müllerian abnormalities is in the general population, because no good cross-sectional studies of healthy patients have been performed. It is believed that the incidence is in the range of $1 \%$ to $6 \%$, with the reported prevalence ranges from $0.16 \%$ to $10 \%$. These disorders are associated with various gestational complications, including spontaneous abortion, intrauterine growth restriction, abnormal fetal lie, preterm labor, and preterm birth. Women with recurrent pregnancy loss (RPL) appear to have a much higher incidence of anomalies relative to the general population ${ }^{(2)}$.A uterine septum is believed to develop as a result of failure of resorption of the tissue connecting the two paramesonephric (Mullerian) ducts prior to the $20^{\text {th }}$ embryonic week. The true prevalence of the uterine septum is difficult to calculate as many uterine septum defects are asymptomatic, but appear to range between 1 to 2 per 1,000 to as high as 15 per 1,000 . Septate uteri have a spectrum of configurations including incomplete/partial septate to complete septate uterus. A partial septate uterus refers to a single fundus and cervix with a uterine septum extending from the top of the endometrial cavity toward the cervix. The size and shape of the septum can vary by width, length and vascularity ${ }^{(3)}$. Initially, uterine septa were believed to be predominately fibrous tissue. However, biopsy specimens and magnetic resonance imaging (MRI) suggest that septa are composed primarily of muscle fibers and less connective tissue ${ }^{(4)}$. With the development of gynecological endoscopic technology, the diagnostic and treatment techniques of uterine septum are continuously being improved and perfected. Transcervical resection of the septum (TCRS), with advantages such as shorter operating time, less surgical trauma and fewer complications, has become increasingly popular in clinical application ${ }^{(5)}$. The common methods of TCRS include electroresection, microscissors, and laser. Microscissors do not require cervical dilation or cause thermal damage to surrounding tissues and organs, and they can reduce the electrosurgical risks and occurrence of water intoxication. However, their drawbacks include the impossibility of synchronized bleeding stop, a relatively long operating time and excessive equipment wear and the requirement for regular replacement of the scissors. Laser surgery has a short operating time, a lower amount of bleeding, a good haemostatic effect, and no damage to surrounding organs, and it can be used in all types of uterine distention fluids. However, it still has some disadvantages-its high cost, high operation requirements, and increased risk of gas embolism caused by application of 
some gases.Comparatively, the procedure of hysteroscopic electrosurgical excision of the uterine septum is more widely accepted and used among endoscopists. If the separation is too deep, damage may be caused to the uterine muscle wall, resulting in heavy bleeding or even uterine perforation, whereas if the separation is too shallow, residual septum may occur, affecting the surgical outcomes ${ }^{(7)}$. The aim of this study was the assessment of the histological features of the uterine septum as regard the proportion of muscle fibers in relation to fibrous tissue to decide the best management whether incision or excision ${ }^{(\boldsymbol{G})}$.

\section{PATIENTS and METHODS}

This cross sectional study was done in early cancer detection and endoscopy unit, Ain Shams Maternity Hospital. It was done on 16 patients in child bearing period complaining of infertility or recurrent pregnancy loss or preterm deliveries and diagnosed to have uterine septum. Patients with pelvic inflammatory disease or pregnancy or uterine myomas were excluded from the study. The study was approved by the Ethics Board of Ain Shams University.

\section{Method}

The procedure was done by early cancer detection unit team. After a written informed consent. The women were prepared for either office or operative hysteroscope. In case of operative hysterescope, women were subjected to regional or general anesthesia. Cleaning of the vulva and vagina by povidone iodine $10 \%$. After bimanual examination dilatation of the cervix to Hegar 9 was done if resectoscope was used but if office hysteroscope was used there was no need for dilatation. The office hysteroscope which was used is rigid hysteroscope (karl storz, Tuttlingen, Germany) (Telescope: rigid, $30^{\circ}$ Hamou II lens system). The sheath had a $5 \mathrm{~mm}$ outer diameter, with $2.9 \mathrm{~mm}$ rod lens. The hystero-resectoscope which was used is rigid hysteroresectoscope with continuous flow (27 French, 9-mm outer sheath and 8-mm inner sheath, 30-degree fore-oblique telescope, karl storz, Germany). A high intensity light source and fiberoptic cable (Germany) (Xenon nova, model 20131520 manufactured by storz) was used to illuminate the uterine cavity. The intrauterine pressure was adjusted through Hamou Hysteromat (Karl Storz, Tüttlingen, Germany) with the aim of maintaining the lowest pressure required to distend the cavity. Introducing of the hysteroscope was done using glycine as distension medium in case of using monopolar resectoscope or saline in case of office hysteroscopy. The septum was incised or excised by scissors or by resectoscope, and then specimen was taken from the middle of the septum (sample A) and another specimen from the uterine wall (sample B). The retraction of the septal tissue to the uterine wall was observed.

Histopathological examination of the uterine septum and the uterine wall was done. The study included 16 specimens of uterine septum (A) and 16 specimens from uterine wall (B). Routine staining with hematoxylin and eosin was done. Special stain of Masson's trichrome to detect muscle fibers and Periodic Acid-Schiff to detect ground substance of connective tissue was also done for all specimens. Each slide was examined by a pathologist who was blind about the location from which the samples were taken using Zeiss microscope, with a magnification of $\mathrm{X}$ 400. Muscular tissue appeared as longitudinal, transverse and oblique bundles of long fusiform, deeply eosinophilic fibers with central rod shaped nuclei. In contrast, the connective tissue proper was formed of scattered, widely separated pale, ill defined fibroblasts among prominent extracellular matrix (acidophilic collagen and ground substance). Blood vessels were small capillaries, (thin wall lined by endothelium, no muscle wall) Large venule, (dilated lumen, thin muscle wall) Arteriole (narrow lumen, thicker muscle wall). All fields were examined for each specimen with scoring of amount of connective tissue, muscles, and vessels.

\section{Statistical analysis}

Data were fed to the computer and analyzed using IBM SPSS software package version 20.0. (Armonk, NY: IBM Corp) Qualitative data were described using number and percent. Quantitative data were described using range (minimum and maximum), mean, standard deviation and median. Significance of the obtained results was judged at the 5\% level.

\section{RESULTS}

The distribution of cases according to the demographic information was shown in table 1. 
Table 1: descriptive data of demographic information

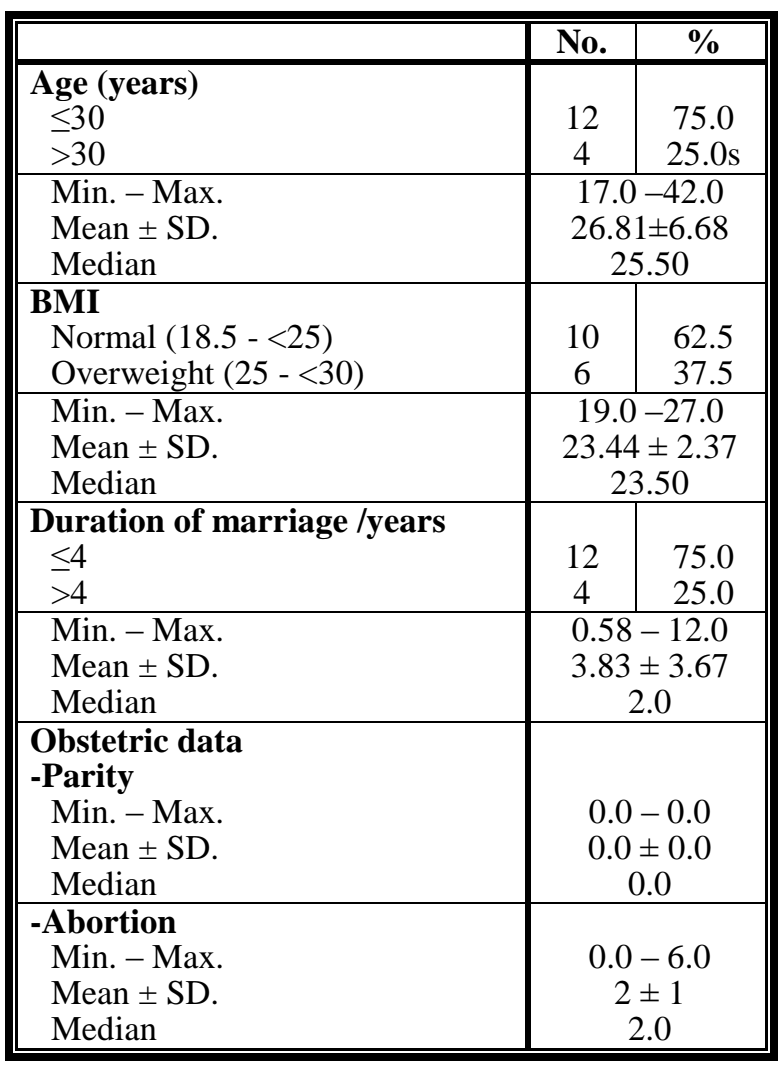

Table 2 showed comparison between the histopathological characteristics of the uterine septum and the uterine wall. There was a statistical significant difference between the uterine septum and the uterine wall regarding amount of connective tissue, number of cells in connective tissue, amount of muscle tissue, amount of capillaries and number of vessels with muscle wall $(\mathrm{P}<0.05)$.Table 3 indicated comparison between the uterine wall and the uterine septum regarding the relation between muscle and fibrous tissue. In uterine septum biopsies there were 3 biopsies that had muscle more than fibers (similar to the uterine wall) and 13 biopsies had fibers more than muscle. While in uterine wall biopsies all biopsies had muscle more than fibers. Table 4 revealed comparison between uterine septa contain muscle $>$ fiber and those contain Fiber $>$ muscle according to retraction of septal tissue during hysteroscopy. Poor retraction occur in all uterine septa that contain muscle $>$ fibers. While in uterine septa that contain fibers > muscle, good retraction occur in 11 septa (84.6 $\%$ ) and poor retraction occur in 2 septa $(15.4 \%)$.
Table 2: showing comparison between the histopathological characteristics of the uterine septum and the uterine wall

\begin{tabular}{|c|c|c|c|c|c|c|}
\hline & \multicolumn{2}{|c|}{$\begin{array}{l}\text { Uterine } \\
\text { septum } \\
(\mathrm{n}=16)\end{array}$} & \multicolumn{2}{|c|}{$\begin{array}{c}\text { Uterine } \\
\text { wall } \\
(\mathbf{n}=\mathbf{1 6})\end{array}$} & \multirow[t]{2}{*}{$\mathbf{Z}$} & \multirow[t]{2}{*}{$\mathbf{p}$} \\
\hline & No. & $\%$ & No. & $\%$ & & \\
\hline $\begin{array}{l}\text { a- Amount } \\
\text { of fibrous } \\
\text { tissue }\end{array}$ & & & & & & \\
\hline Grade I & 2 & 12.5 & 10 & 62.5 & & \\
\hline Grade II & 7 & 43.8 & 6 & 37.5 & $2.765^{*}$ & $0.006^{*}$ \\
\hline Grade III & 7 & 43.8 & 0 & 0.0 & & \\
\hline $\begin{array}{l}\text { b-Number } \\
\text { of cell in } \\
\text { C. } T\end{array}$ & & & & & & \\
\hline Nil & 0 & 0.0 & 8 & 50.0 & & \\
\hline Grade I & 0 & 0.0 & 8 & 50.0 & $3.619^{*}$ & $<0.001^{*}$ \\
\hline Grade III & 16 & 100.0 & 0 & 0.0 & & \\
\hline $\begin{array}{l}\text { c-Amount } \\
\text { of muscle } \\
\text { tissue }\end{array}$ & & & & & & \\
\hline Nil & 1 & 6.3 & 0 & 0.0 & & \\
\hline Grade I & 4 & 25.0 & 0 & 0.0 & $3275^{*}$ & $0001^{*}$ \\
\hline Grade II & 8 & 50.0 & 0 & 0.0 & 3.275 & 0.001 \\
\hline Grade III & 3 & 18.8 & 16 & 100.0 & & \\
\hline $\begin{array}{l}\text { d-Amount } \\
\text { of } \\
\text { capillaries }\end{array}$ & & & & & & \\
\hline Grade I & 2 & 12.5 & 0 & 0.0 & & \\
\hline Grade II & 11 & 68.8 & 0 & 0.0 & $3.419^{*}$ & $0.001^{*}$ \\
\hline Grade III & 3 & 18.8 & 16 & 100.0 & & \\
\hline $\begin{array}{l}\text { E-Amount } \\
\text { of vessels } \\
\text { with } \\
\text { muscle } \\
\text { wall }\end{array}$ & & & & & & \\
\hline Grade I & 4 & 25.0 & 0 & 0.0 & & \\
\hline Grade II & 8 & 50.0 & 0 & 0.0 & $3.176^{*}$ & $0.001^{*}$ \\
\hline Grade III & 4 & 25.0 & 16 & 100.0 & & \\
\hline
\end{tabular}

$\mathrm{Z}, \mathrm{p}: \mathrm{Z}$ and $\mathrm{p}$ values for Wilcoxon signed ranks test for comparing between cases and control

*: Statistically significant at $p \leq 0.05$

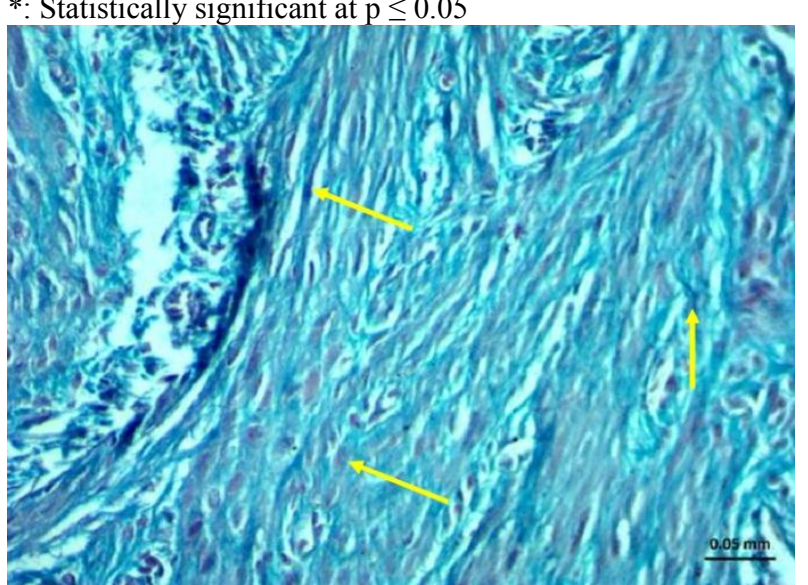

Figure 1: fibrous septum nil muscles, GIII fibrous tissue (arrows) (Masson's trichrome stain). 


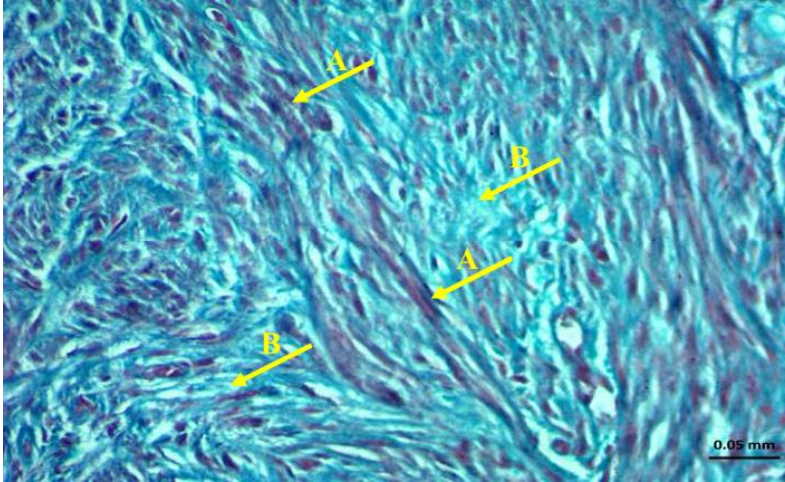

Figure 2: fibrous septum GI muscles (A), GIII fibrous tissue (B) (Masson's trichrome stain).

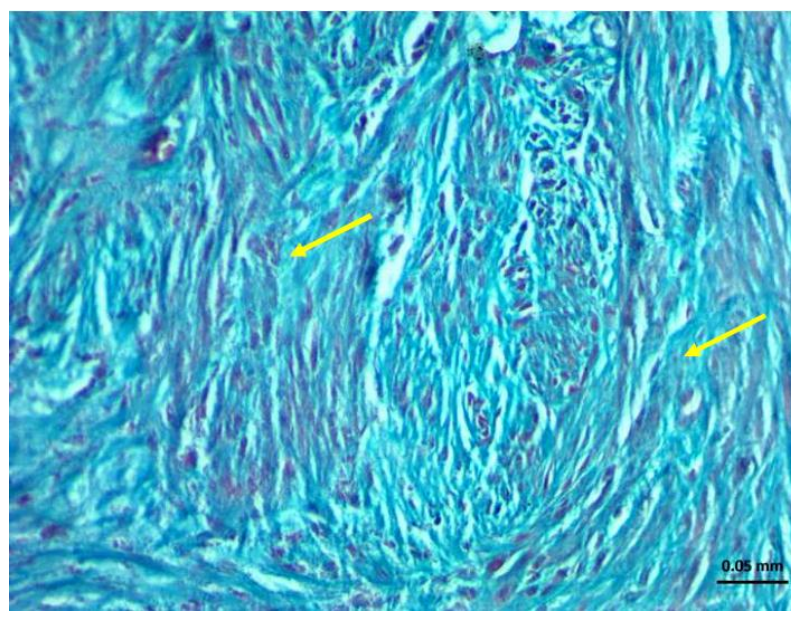

Figure 3: fibrous septum: high cellularity in fibrous septum( Masson's trichrome stain).

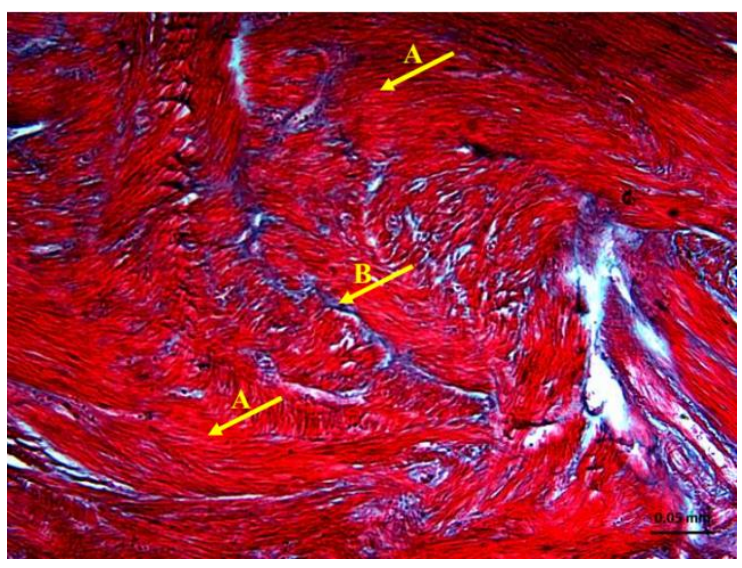

Figure 4: muscular septum, GIII muscle fibers (A), minimal fibrous tissue (B)(Masson's trichrome stain).

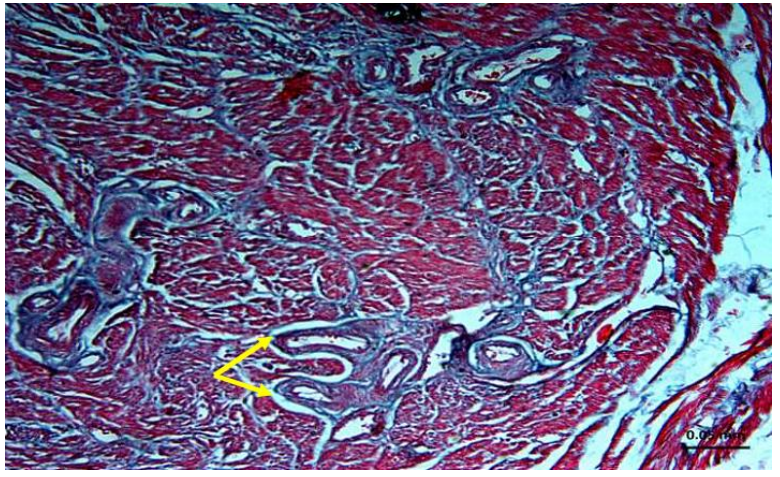

Figure 5: numerous capillaries in muscular septum (Masson's trichrome stain).

Table 3: comparison between uterine wall and uterine septum biopsies according to the relation between muscle and fibrous tissue

\begin{tabular}{|c|c|c|c|c|c|c|}
\hline & \multicolumn{2}{|c|}{$\begin{array}{l}\text { Uterine } \\
\text { septum } \\
(\mathrm{n}=16)\end{array}$} & \multicolumn{2}{|c|}{$\begin{array}{c}\text { Uterine } \\
\text { wall } \\
(\mathbf{n}=\mathbf{1 6}) \\
\end{array}$} & \multirow[t]{2}{*}{$\chi^{2}$} & \multirow[t]{2}{*}{$\mathbf{P}$} \\
\hline & $\begin{array}{c}\text { No } \\
\text {. }\end{array}$ & $\%$ & $\begin{array}{c}\text { No } \\
\text {. }\end{array}$ & $\%$ & & \\
\hline $\begin{array}{l}\text { Muscl } \\
e> \\
\text { fiber }\end{array}$ & 3 & $\begin{array}{c}18 . \\
8\end{array}$ & 16 & $\begin{array}{c}100 . \\
0\end{array}$ & \multirow{2}{*}{$\begin{array}{c}21.89 \\
5^{*}\end{array}$} & \multirow{2}{*}{$\begin{array}{c}<0.00 \\
1^{*}\end{array}$} \\
\hline $\begin{array}{l}\text { Fiber } \\
> \\
\text { muscl } \\
\text { es }\end{array}$ & 13 & $\begin{array}{c}81 . \\
3\end{array}$ & 0 & 0.0 & & \\
\hline
\end{tabular}

$\chi^{2}, \mathrm{p}: \chi^{2}$ and $\mathrm{p}$ values for Chi square test for comparing between the two groups

*: Statistically significant at $\mathrm{p} \leq 0.05$

Table 4: comparison between uterine septa that contain muscle $>$ fiber and uterine septa that contain Fiber >muscle according to retraction of septal tissue during hysteroscopy

\begin{tabular}{|c|c|c|c|c|c|c|}
\hline \multirow{2}{*}{$\begin{array}{c}\text { Retractio } \\
\text { n of septal } \\
\text { tissue } \\
\text { during } \\
\text { hysterosco } \\
\text { py }\end{array}$} & \multicolumn{2}{|c|}{$\begin{array}{c}\text { Muscle }> \\
\text { fiber } \\
(n=3)\end{array}$} & \multicolumn{2}{|c|}{$\begin{array}{l}\text { Fiber }> \\
\text { muscles } \\
(n=13)\end{array}$} & \multirow{2}{*}{$\mathbf{x}^{2}$} & \multirow{2}{*}{${ }^{\mathbf{F E}} \mathbf{p}$} \\
\hline & $\begin{array}{l}\mathbf{N} \\
\text { o. }\end{array}$ & $\%$ & $\begin{array}{l}\mathbf{N} \\
\text { o. }\end{array}$ & $\%$ & & \\
\hline $\begin{array}{l}\text { Poor } \\
\text { retraction }\end{array}$ & 3 & $\begin{array}{c}100 . \\
0\end{array}$ & 2 & $\begin{array}{c}15 . \\
4\end{array}$ & \multirow{2}{*}{$\begin{array}{c}8.71 \\
2^{*}\end{array}$} & \multirow{2}{*}{$\begin{array}{c}0.01 \\
8^{*}\end{array}$} \\
\hline $\begin{array}{l}\text { Good } \\
\text { retraction }\end{array}$ & 0 & 0.0 & 11 & $\begin{array}{c}84 . \\
6\end{array}$ & & \\
\hline
\end{tabular}

$\chi^{2}, p: \chi^{2}$ and $p$ values for Chi square test for comparing between the two groups

${ }^{\mathrm{FE}} \mathrm{p}$ : $\mathrm{p}$ value for Fisher Exact for Chi square test for comparing between the two groups

*: Statistically significant at $\mathrm{p} \leq 0.05$ 


\section{DISCUSSION}

Hysteroscopic treatment of the septum may be done in more than one session due to presence of residual septum. Kormányos et al. ${ }^{(8)}$ found that after operative hysteroscopy for 94 women with uterine septum normal uterine architecture (complete removal of the septum) was achieved in 58 patients (62\%), and a residual fundal septum was found in 36 patients $(38 \%)$. This study was carried out on 16 women with uterine septum in childbearing period complaining of either infertility or recurrent miscarriage fulfilling the inclusion criteria, attending to Ain Shams University Maternity Hospital between May 2017 and April 2018. During hysteroscopic removal, the retraction of the septal tissue to both uterine walls was observed. Biopsies from the uterine septum and the uterine wall were taken.Each biopsy was examined by a pathologist who was unaware of the location from which the samples were taken.In our study there was a statistical significant difference between the two groups regarding amount of fibrous tissue, number of cells in connective tissue, amount of muscle tissue, amount of capillaries and number of vessels with muscle wall $(\mathrm{P}<0.05)$. In the uterine wall biopsies (myometrium), the muscle fibers showed regular arrangement in the form of longitudinal, transverse, and interlacing fibers with little hypocellular connective tissue in between with vessels and capillaries more than 5 in a field of $x 100$. In contrast, in the uterine septum biopsies there were thirteen cases showed irregular arrangement in the form of short haphazard fascicles widely separated by hyper cellular connective tissue from which 6 cases with vessels and capillaries less than 2 in a field of $\mathrm{x} 100$ and 8 cases with vessels between 2-5 of a field of $x 100$ and 3 cases with vessels more than 5 in a field of $x 100$. The other three cases showed regular arrangement in the form of longitudinal, transeverse, and interlacing fibers with little hypocellular connective tissue in between which is similar to the myometrium with vessels and capillaries between 2-5 of a field of $x 100$ in 2 cases and more than 5 of a field of $x 100$ in one case. Also, in the three cases in which the biopsies of the septum was similar to the myometrium, there were poor retraction of the septal tissue during septum incision. In contrast, there was a good retraction in the other thirteen cases in which the biopsies showed irregular arrangement in the form of short haphazard fascicles widely separated by hypercellular connective tissue. In agreement of our results, March ${ }^{(9)}$ stated that the septum is a fibroelastic band that retract quiet easily with only scanty bleeding. Also, Fayez ${ }^{(10)}$ carried out a study to compare between abdominal and hysteroscopic metroplasty in which he did hysteroscopic metroplasty for nineteen women, found that the septum is composed of fibromuscular tissue characterized by being less cellular and more collagenous, with scanty vasculature and a poorly developed endometrium.

Also, Sparac et al. ${ }^{(6)}$ found that in 55 patients (72.3\%) histologic analysis of resected uterine septum showed fibromuscular structure with slightly more pronounced connective tissue component. In 21 (27.6\%), septa were composed of tissue identical to that of myometrium and the uterine septa did not consist of connective avascular tissue, but rather of very well-vascularized fibromuscular tissue.In contrast with our findings Dabirashrafi et al. ${ }^{(11)}$ stated that the septum composed of more muscles and less CT. The difference between the two studies may be due to increase number of biopsies taken by Dabirashrafi from each case. It also may be due to the different method of biopsy taking as Dabirashrafi take the biopsy during Tompkins metroplasty but in our study the biopsies were taken by hysteroscopy.

In another study performed in Mansoura University by Gouhar and Siam ${ }^{(4)}$ they found that among 29 cases with septate uterus, histology of the septum showed myometrial tissue with normal vascularization (muscular septum) in 19 patients, and prominent fibrous tissue with poor vascularization (fibrous septum) in 10 patients. The difference between the two studies may be due to the difference in number of studied cases. Our study showed the histologic features of the uterine septum as regard fibrous tissue, muscle tissue and vascularity. From the sixteen uterine septa three of them were similar to the myometrium and the other thirteen had fibrous tissue more than muscular tissue with variant of vasculature; so the septum composition may be muscular or fibrous and surely, knowing the histologic component of the septum prior to the treatment will help in deciding the best management either incision or excision. So there 
is a need for non-invasive imaging technique to determine the composition of the septum as regard proportion of muscle and fibers and vasculature. In conclusion, we could indicate that the structure of the septum is variable and the majority is predominately fibrous and the minority is predominately muscular. Poor retraction of the septal tissue was found in the muscular septum in contrast to good retraction that found in fibrous septum. Assessment of the histologic features of the septum will assess in deciding the best management either incision or excision according to the proportion of muscle and fibrous. Alternative non-invasive method to know the structure of the septum prior to treatment may be needed.

\section{REFERENCES}

1. Cruveilhier DWJ, Rokitansky CV and Virchow R (1978): Fundaments of pathology, thoughts on the 100th anniversary of Rokitansky's death. Virchows Arch Pathol. Anat. Histol., 378:1-16.

2. Deutch RD and Abuhamad AZ (2008): The role of 3-dimensional ultrasonography and magnetic resonance imaging in the diagnosis of Müllerian duct anomalies: a review of the literature. J. Ultrasound Med., 27:4113-423.

3. Valle RF and Sciarra JJ (1986): Hysteroscopic treatment of the septate uterus. Obstet. Gynecol., 67:253-257.

4. Gouhar GK and Siam S (2013): Uterine septum structure and reproductive performance: Role of 3D TVUS and MRI. Egyptian J. Radiol. Nuclear Med., 44(2): 357-65.

5. Pellerito JS, McCarthy SM, Doyle MB, Glickman MG and DeCherney AH
(1992): Diagnosis of uterine anomalies: relative accuracy of MR imaging, endovaginal sonography, and hysterosalpingography. Radiology, 183:795-800.

6. Sparac V, Kupesic S, Ilijas M, Zodan Tand Kurjak A (2001): Histologic architecture and vascularization of hysteroscopically excised intrauterine septa. The Journal of the American Association of Gynecologic Laparoscopists, 8(1):111-117.

7. Wang $S$, Shi $X$, Hua $X$, Gu $X$ and Yang D (2013): Hysteroscopic transcervical resection of uterine septum. JSLS., 17(4):517-520.

8. Kormányos Z, Molnár BG and Pál A (2006): Removal of a residual portion of a uterine septum in women of advanced reproductive age: obstetric outcome. Human Reproduction, 21(4):1047-1051.

9. March CM (1983): Hysteroscopy as an aid to diagnosis in female infertility. Clinical Obstetrics and Gynecology, 26(2):302-12.

10. Fayez JA (1986): Comparison between abdominal and hysteroscopic metroplasty. Obstetrics and Gynecology, 68(3):399403.

11. Dabirashrafi H, Mohammad K, Moghadami-Tabrizi N, Zandinejad K and Moghadami-Tabrizi $M$ (1996): Is estrogen necessary after hysteroscopic incision of the uterine septum? J. Am. Assoc. Gynecol Laparosc., 3:623-628. 